\title{
Liberal rule through non-liberal means: the attempted settlement of Irish Travellers (1955-1975)
}

\author{
Una M. Crowley \\ Department of Geography and NIRSA, National University of Ireland, Maynooth
}

\begin{abstract}
In 1963, after the publication of the Report of the Commission on Itinerancy, the Irish Government embarked on a national programme for the 'settlement', 'assimilation' and 'rehabilitation' of Irish Travellers. This paper is concerned with the power effects of discourses both driving and mobilised by the Report and with how liberal forms of thought and political rationality have considered the treatment of individuals and groups considered to be without the 'attributes of juridical and political responsibility' (Dean, 1999: 134). The paper describes how Traveller society was 'imagined' and reconstructed during this period through elite discourse and the use of statistical inscriptions; how these mechanisms of representation facilitated and legitimated intervention into their everyday lives, rendered Travellers visible and permitted their characterisation as a 'group', a 'community' in need of reform.
\end{abstract}

Key index words: Irish Travellers, governmentality, bio-politics, settlement.

\section{Introduction}

Within liberal forms of government...there is a long history of people who, for one reason or another, are deemed not to possess or to display the attributes (e.g. autonomy, responsibility) required of the juridical and political subject of rights and who are therefore subjected to all sorts of disciplinary, bio-political and even sovereign interventions. (Dean, 1999: 134)

This paper draws from a perspective on governmentality that Dean (1999) refers to as 'authoritarian' or 'non-liberal' governmentality. It is a perspective that highlights questions of non-liberal rule within a liberal democracy and is applied to certain populations categorised as being without the 'attributes of responsible freedom' or those excluded from 'the status of the autonomous rational person' (p.131). In common with traditional Foucauldian perspectives on governmentality, non-liberal governmentality carries out its analysis from the perspective of government where government is thought of as a broader concept than the monolithic entity of the State. It draws attention to a certain way of thinking and acting embodied in all those attempts to know and govern individuals and groups. However, in this case, mechanisms and devices, calculations, inscriptions and mundane programmes that give effect to governmental objectives operate through different articulations of pastoral power and disciplinary logic. Selfhelp, self-regulation and self-control strategies are punitive and coercive (initially at any rate) and involve, at different levels, the two poles of 'power over life' that Foucault (1979: 1982) identified - the disciplines of the body (the optimisation of the body's capabilities through manipulation, education, training, punishment and reward) and bio-politics (a form of politics necessitating the administration of the processes of life of the population).

For Foucault the focus on bio-politics 'brought life and its mechanism into the realm of explicit calculation and made knowledge-power an agent of transformation of human life' (1980: 143). Bio-politics is concerned with governance of matters concerning life and death, 
birth, morbidity, propagation, health, hygiene, education and so on. Following this, it is concerned with the economic, social, environmental and geographic conditions under which people live (for example, family, housing, living and working conditions, pastimes) and with how certain 'behaviours' are facilitated and encouraged or impeded and suppressed with the ultimate aim of producing, 'at a distance a particular ordered society under prevailing political rationalities' (Rose, 1999 cited in Prince, 2004: 3). It is through the dividing practices inherent in bio-politics that populations are categorised into sub-groups of 'those that contribute to or retard the general welfare and life of the population' (Dean, 1999: 100).

The Report of the Commission on Itinerancy, 1963 (COI), which mobilised a national settlement, assimilation and rehabilitation programme for Travellers (Ireland's indigenous nomadic population), was itself driven by a rapidly changing social, cultural and political climate in Ireland that was epitomized in a series of reports on economic and social matters published by the National Economic and Social Council (a government appointed advisory body) in the late 1950s. It marked a major shift in social policy from the anti-interventionist stance supported by the Catholic Church towards increased State involvement. It was a period when the basis of the national development strategy was laid which propelled the economy towards unprecedented growth in the fifteen-year period 1958-73. This change in attitude and direction gave rise to a new form of thought and political rationality that was to have a profound effect on how the Irish population (particularly its nomadic population) was managed and governed.

Within a few years of the publication of the Report in 1963 there was a spread of institutions (both formal and informal) and surveillance into every aspect of Traveller life where before there was very little (for example, into aspects of cultural development, health, hygiene, parenting, housework, training schemes, education, accommodation and so on). It was not the case of established methods of disciplining and controlling Travellers declining (in fact evictions, prosecutions and harassment continued unabated) but that it was augmented with newer more subtle and systematic methods of discipline and control. 'Self-help' programmes and policies simultaneously 'encouraged' and 'coerced' Travellers to recognise their moral, social and economic obligations and responsibilities to Irish society. This new productive mode of governing Travellers would attempt to reconstruct, 'rehabilitate' and assimilate Travellers rather than merely trying to contain them - 'to produce new gestures, actions, habits and skills and ultimately new kinds of people, ready to return to society' (Gutting, 1994: 84-85).

Part one of this paper sets the context and describes how Travellers' lives were (re)constructed, made knowable through discursive practices (such as legal, religious, criminality, pathology, citizenship, xenophobia and so forth) and how these ways of observing and thinking about Travellers rendered them visible and through this visibility, open to intervention. The paper provides a broad framework for understanding how the Irish State 'problematised' the existence of Irish Travellers and sought to act in response to the resulting 'problematisations'. It demonstrates how the process of subjectification is made possible (and plausible) through stereotypical discourse (van Dijk, 1997: 39) and how different discourses (both old and new) fed off and into each other in self-reinforcing ways. The paper details how certain non-liberal forms of thought and actions concerning Travellers increasingly gained legitimacy. It unearths the moral, ethical and conceptual conditions under which it become possible for the different authorities and charitable organisations to considerate it legitimate and necessary to settle, 'assimilate' and 'rehabilitate' Travellers. 
Part two focuses on the technologies of government and examines how, and with what effect, the Report rendered Travellers' lives 'governable by being formulated in a particular conceptual way’ (Townley, 1998: 193-4). This centrally planned, social engineering project was characterised by a system of knowledge that was driven by economic and social concerns and an obsessive desire to categorise and classify. The importance and impact of this Report cannot be over emphasised; it constructed Travellers existence in 'a particular way, under the guise of knowing it' (Said, 1978: 3), gave effect to governmental ambitions and most importantly it produced a space for the somatic disciplining of supposedly unruly Travellers. Not only did this Report as a 'technology' of government exhibit its own 'will to truth' and declare the abnormality and deviancy of Travellers but it would, over the next 50 years or so, be built on, exert a 'pressure', a 'power constraint' on other discourses (Hunt, 1994) and crucially begin to create rather than reflect history.

\section{Political rhetoric (1955-1963)}

The language that constitutes political discourse is more than rhetoric. It should be seen, rather, as a kind of intellectual machinery or apparatus for rendering reality thinkable in such a way that it is amenable to political deliberations (Rose and Miller, 1992:179).

The years immediately preceding the launch of the National Settlement Programme in 1963 was a time of great trauma, upheaval and uncertainty in Irish economic, social life and cultural life. Feelings of anxiety and disillusionment gradually intensified as the post revolutionary State failed to fulfil its promises and many social problems not only remained unsolved but, in fact, got worse. Poverty was endemic and levels of emigration and unemployment rose steadily. 'More than 500,000 people abandoned 'traditional' Ireland between 1945 and 1961 as the wave of emigration surged forward' (Lee, 1979: 169). The population had declined to 2.8 million, five percent lower than when the State was founded in 1922. Ireland's overall growth performance in the 1950s was the worst in Europe and confidence about the viability of the economy reached an all time low.

During this period Travellers served as a 'suitable enemy' (Christie, 1984), enabling a self-righteous discharge of aggression and facilitating the transfer of guilt and disillusionment away from Irish society (MacLaughlin, 1995; Ní Shúinéar, 1997; Helleiner, 2000). In Dáil debates verbal assaults on Travellers escalated - they were accused of stealing, criminality, lacking religion, of being anti-citizen, fraudulent and so on (for example, O'Malley, 13 July 1955: 726-7; Manley, 13 July 1955: 736; Burke, 13 July 1955: 737-8; Coogan, 20 June 1956: 636; Lynch, 11 July 1956: 665; Rooney 11 July 1956: 710). According to Deputy Burke there was a need to 'protect our people against them', from their 'invasions' (11 July 1956: 666667). Captain Giles referred to Travellers as 'little savages who do not believe in God or man' and that this 'should not be tolerated in a Christian country' (11 July 1956: 684-685).

The spread of these ideas were given an increased impetus from 1957 on as the Irish government embarked on a new strategy of foreign led industrialisation. As a class of people thought to be incorrigibly uncivilised, Travellers were viewed as a hindrance to progress and modernisation, and their increasing numbers and visibility became an embarrassment. For many the settlement and assimilation of Travellers was seen as a necessary part of the larger project of national economic and social development (MacLaughlin, 1995; Helleiner, 1997, 2000). The question of introducing legislation with increased powers of eviction was continually brought up in the Dáil (for example, Casey, 18 May 1960, vol., 181; Taylor, 19 May 1960, vol., 181; Ryan, 24 March 1960, vol. 180; O’Donnell, 23 May 1962, vol. 195). 
What gave these elite discourses such strength and emotional power is that they were not merely responding to Travellers in the here and now but building on, and reinforcing the denigration and stigmatisation of Travellers and Gypsies by politicians at home and abroad during the War years (Crowley, forthcoming) and also to discourses mobilised in earlier eras (see Helleiner, 1995: 2000; MacLaughlin, 1995; Ní Shúinéar, 1997: 2002). Each discourse added cumulatively to the ones previously established, thus multiplying the possibilities for anti-nomadic discourse and cementing sedentary society's hostility towards Travellers. Through these dividing practices Travellers were increasingly categorised as a sub-group that held back the general welfare and life of the Irish people. Efforts by elites to remove Travellers from public space became progressively more pervasive and there was increased pressure on Central and Local Government to 'control and settle itinerants'. Health inspectors voiced concern about the 'insanitary conditions of their dwellings' and had received complaints from property owners, business people and farmers (Gmelch, 1985).

For Travellers, the material consequences of these discourses were various forms of harassment, evictions, colonisation of traditional halting sites and increased surveillance. Nomadism was increasingly becoming a condition of rejection rather than that of Otherness. Travellers' symptomology constituted an image that marked geographical as well as social space - they were drop-outs, trespassers, alcoholic and criminal. Drastic action was thus required to regulate the boundaries that contained them and arrest any sign of diffusion - the crucial problem was now rehabilitation - recalling them from their state of abjection and reintegrating them into respectable society (Procacci, 1991).

The Irish State was, however, faced with the problem of how it could govern Travellers and regulate their mobility in ways that would be seen to be consonant with liberal democratic ideals ('free' space beyond the confines of the State must be upheld while at the same time regulated) and avoid as one Councillor put it; '... acting in an unChristian and undemocratic manner which would eventually be quoted by the press behind the Iron Curtain [After all] as citizens of the State they were entitled to the protection of the Constitution' (Monaghan, September 1952, Meath County Council). The solution came through the promotion of the idea of Travellers as anti-citizen, as a population without the attributes of 'responsibility and autonomy'. The doctrine of liberty need only apply to those 'human beings in the maturity of their faculties' (Valverde, 1996 cited in Dean, 1999: 133). Travellers were only entitled to the same treatment as everybody else if they became 'respectable decent citizens'. In the Dáil, Russell argued:

I do not want to be taken as questioning the right of these people to live. They have a perfect right to live. Indeed every public representative in Limerick takes the view that if they are prepared to settle down and become respectable decent citizens, they will be as welcome in Limerick as any place else. But they do not do that. They live on the people, destroy property, frighten women and children, and are a menace to tourists. (15 April 1958: 163)

Governments foster citizenship in order to enhance a sense of individual responsibility and self-policing for the welfare of the community. 'On this account, good citizens gain public benefits in return for appropriate private behaviour. The good person internalises and incorporates the values of society and in return is accorded the rights and entitlements of citizenship' (Pile, 1995: 201). By demonstrating their inability or refusal to adapt to the norms of citizenship Travellers were automatically excluded from the status of the autonomous and rational person. 
Although there was no legislation that specifically related to Travellers and their nomadic way of life Local Authorities increasingly resorted to using Part 1V of the Local Government (Sanitary Services) Act, 1948, to counter Travellers' presence and frustrate their way of life. The Act enabled Local Authorities to make bye-laws regulating the use of temporary dwellings and the use of land for camping in their district and in particular to provide for the prevention of destruction to the amenities of a locality by reason of dirt, scrap, litter or noise from the temporary dwelling and for the prevention of nuisance. Temporary dwellings could be destroyed if they were considered to be a danger to public health or interfere with traffic. Penalties for illegal encampment varied from fines, confiscation of dwellings and imprisonment. The Sanitary Services Act of 1948 had extended well beyond sanitary supervision and, although it did not explicitly relate to Travellers, 'at least one sanitary authority employ[ed] an official whose function is to keep itinerants in the area on the move' (COI, 1963:53). This 'official' intervention into Travellers' lives offered the Garda and Local Authorities an easy opportunity for general surveillance. Along with its formal aims, this Act was also used as part of an effort on behalf of local authorities to contain Travellers' occupational and geographical mobility. The fragile social equilibrium between toleration and segregation of marginal social behaviour that was necessary to the survival of Travellers as a nomadic group was almost certainly upset by the enforcement of the Sanitary Services Act. By highlighting behaviour that was once informally tolerated, these judicial measures combined with efforts of moral reformers, were making ever clearer that distinction between respectable and unrespectable behaviour, thereby facilitating the social isolation and marginalisation of Travellers. The very title of the Act encouraged links with earlier discourses on the relationship between mobility, health and the spread of disease.

By 1960, complaints about Travellers obstructing roads, destroying property and leaving sites littered with scrap and rubbish had grown so much that health inspectors submitted a formal request to appoint a commission to investigate the problems caused by Travellers and to propose a solution (Gmelch, 1985).

\title{
Report of the Commission on Itinerancy (1963): calculations and inscriptions
}

\author{
It is not difficult... to understand why so many human lives have been destroyed by \\ mobilised violence between ethnic groups, religious sects, or linguistic communities. \\ But it is harder to grasp why so many well-intended schemes to improve the human \\ condition have gone so tragically awry. (Scott, 1998: 4)
}

Once a domain is described and rendered into thought it needs information to measure its condition (Latour, 1986 cited in Rose, 1996: 72). Information establishes a knowledge circuit between authorities, events and persons at a distance from them. It allows aspects of life (health, hygiene, mortality rates, propensity to crime, illiteracy, pastimes, behaviours) to be represented in a calculable form in a place where decisions are to be made about them (for example, Department of Health, Department of Environment, Department of Justice, charitable organisations). Diagnostic categories, evaluation, assessments (health, demography, poverty, pathology and so on) construct the subject in a form in which it can be represented and classified. The translation of individuals into the domain of knowledge makes it possible to govern subjectivity according to norms claiming the status of science, by professional elites grounding their authority in an objective knowledge (Rose, 1996). 
The Report of the Commission on Itinerancy (1963) (COI) marked the first systematic attempt by the Irish government to settle Travellers and was a key influence in the development of statutory and voluntary responses to Travellers. It provided a radically new framework for the management of Travellers. Its ultimate goal of settlement, spatial fixity and individual distinguishability has remained the cornerstone of Government policy towards Travellers ever since.

The use of surveys (carried out by local authorities and the Garda) and censuses (in 1944, 1952, 1956, 1960 and 1961) served as a technique of decipherment, enabling the chaos of nomadism and Travellers existence to be disentangled. The Commission also examined reports from Northern Ireland (1954), Kent County Council (1952) and reports of the Departmental Committees on Vagrancy in Scotland, 1936 and Tinkers in Scotland, 1918 were also obtained (COI, 1963: 15). The Department of External Affairs furnished the Commission with reports from countries throughout Western Europe. The Commission found that: 'The measures most commonly applied are the control of movement, the provision of identity cards, compulsory reporting to the police on arrival in a district, annual registration and other similar methods' (p.15).

Statistics on health, welfare, education, mortality, morbidity and so on constituted a new territory upon which it is possible to act (Cruikshank, 1999). The accumulation of information transformed the Traveller 'problem' into a set of possible actions and allowed Travellers to be disembedded from their individual socio-spatial contexts into a domain that could be represented and opened up to political deliberation and intervention and brought inside the policy process. Government agents in the form of social workers, teachers, council workers, the Church and members of settlement committees would become its exclusive voice, allowing government to 'act at a distance'. The 'truths' and knowledge contained in the report would tie the various actors together and furnish them with a common language, goals and forms of calculation and representation (Murdoch and Ward, 1997: 311).

The power of the report depended not only on bracketing contingency but also on standardising the subjects of development. The Traveller Community planned for in this report was an abstract one; standardised and uniform in its needs. They were generic subjects that needed to be civilised, settled, educated and rehabilitated. Scott's statement in relation to programmes for indigenous peoples in other parts of the world is also relevant here:

What is striking, of course, is that such subjects - like the 'unmarked citizens' of liberal theory - have, for the purposes of the planning exercise, no gender, no tastes, no history, no values, no opinions or original ideas, no traditions, and no distinctive personalities to contribute to the enterprise. They have none of the particular, situated, and contextual attributes that one would expect of any population and that we, as a matter of course, always attribute to elites. (Scott, 1998: 346)

Historical and popular discourse was selectively 'mined', the construction of Travellers as a 'problem', and rehabilitation, settlement and assimilation as the solutions were already apparent in the language used in the Commission's terms of reference:

1. To enquire into the problems arising from the presence in the country of itinerants in considerable numbers;

2. To examine the economic, educational, health and social problems inherent in their way of life;

3. To consider what steps might be taken - 
- $\quad$ To provide opportunities for a better way of life for itinerants;

- $\quad$ To promote their absorption into the general community;

- $\quad$ Pending such absorption, to reduce to a minimum the disadvantages to themselves and to the community resulting from their itinerant habits.

The Report, with its inherent claims to 'truth' and expertise, would provide the limits within which the discursive objects, Travellers, could act and exist. Members of the committee were appointed from the judiciary, Garda, health and education authorities, farming community, charitable organisations and the Church. Individuals were selected ' ...on the basis of [their] known interest in, and specialised knowledge of, some particular aspect of the itinerant problem' and the Government considered itself '...fortunate in having such a well balanced Commission' (COI, 1963: 111). It was emphasised that the committee members would '....require all tenacity of purpose and a very great deal of patience to accomplish [their] mission' (p.111). There was no Traveller representative involved in the Commission.

According to Hall (1997: 8):

Every choice... - to say this about that - is a choice about how to represent 'other cultures'; and each choice has a consequence both for what meanings are produced and for how meaning is produced.

The Commission decided that the best definition of 'itinerant' was a person 'who had no fixed place of abode and habitually wandered from place to place...' (COI, 1963: 12-13). This particular definition of Travellers and the problem they posed, bears a striking resemblance to the vagrant of the nineteenth century (Travellers were actually referred to as vagrants on occasions). It also led to specific strategies to combat it; strategies whose prime target was to alter the disposition, morality and way of life of Travellers, and to enhance their selfregulating capacities.

The Commission's first consideration was given to ways and 'means of ascertaining so far as possible the relevant facts regarding itinerants, their way of life and their impact on and relation to the settled community' (COI, 1963: 13). Results of censuses of Travellers taken by the Garda in 1944, 1952 and 1956 were furnished to the Commission by the Department of Justice. These gave the numbers of Travellers in each county by age group. Because of the perceived unreliability of the information supplied, another census was taken in December 1960 and again in June 1961. The Commission recommended:

... that the opportunity should be availed of to extend its scope to obtain additional information in regard to such matters as family circumstances, age-groups, religion, literacy and other relevant subjects. (COI, 1963: 32)

The Garda and Local Authority Officials were to collect information on:

... the numbers of individuals, the numbers claiming to be able to read/write, the numbers according to religion, sex and age-groups, the numbers holding social insurance cards, number of persons per family, marriage age groups, statistics as to whether the parents of itinerants were themselves itinerants, illness statistics, child statistics under various headings, statistics on travelling habits, statistics on the number of animals and vehicles in the possession of itinerants and the type of family abode on the days of the censuses, other housing experience, statistics relating to the particular skills of itinerants over the age of 14 years and of the trades, if any, which they desired to learn. All of these statistics are set out on a county basis. (1963: 33) 
The Garda also collected information on Travellers' 'criminal tendencies' and although the Commission found that '...itinerants as a body do not constitute a criminal element in the population and they do not have a predisposition to crime', the Report states in its recommendations:

It must be accepted that itinerants are not unintelligent and a certain number of them may be expected to take advantage of lack of action or leniency by those whose duty it is to enforce the law.... Excessive tolerance and leniency by the Courts should be discouraged....[and] Citizens should be encouraged to report offences to the Garda particularly those who claim to be injured parties. Allegations of intimidation by itinerants should be thoroughly investigated and, where proved, the culprit should be dealt with severely....Crimes of violence such as assault, grievous bodily harm and wounding committed against other itinerants cannot be regarded as unexpected among persons with such a lack of education, self-control, discipline and such addiction to intoxicating liquor. (COI 1963: 94)

The language of expertise played a key role in the justification for settlement and for neutralising what are essentially racist, political ideas. As Miller and Rose (1990: 10) have argued: ' ...its norms and values are compelling because of their claim to disinterested truth, and the promise of offering the desired results'. Note how Travellers are referred to by using the exclusionary pronoun 'them' while members of the settled community are referred to as 'citizens'. Travellers are patronisingly referred to as 'not unintelligent'; their crimes of violence are not 'unexpected' in such an 'uncivilised' group.

Their lack of self-control and discipline was also considered to be due to their lack of appropriate pastimes. The Commission noted:

The itinerant way of life is barren of those forms of relaxation such as football, hurling or other such other outdoor sports available to the settled population. No indoor pastime or relaxation save the cinema is available to them. Boisterous gatherings with excessive consumption of alcoholic drink constitute one of the few pastimes available to them and it is not surprising that so many of these gatherings end in conflict. (COI, 1963: 87)

The Commission recommended 'increased penalties' and that the Garda continued to use the provisions of the Vagrancy (Ireland) Act, 1847, and the Children Act of 1908 (COI, 1963: 92). The Commission felt that:

... a strict enforcement of the law, at least in the early years, would have a salutary effect on the itinerants who, with their usually realistic outlook on life, would soon have a greater respect for the rights of the settled population once they realised that the authorities were serious about the enforcement of the law and that the consequences of disregarding it on either the criminal side and or the civil side could not be avoided. (COI, 1963: 104)

\section{'Illiteracy and its effects'}

According to the Committee the main focus for literacy programmes would have to be on the children as: 'Little can be done about the problem of illiteracy among adult itinerants' (COI, 1963: 70). Implicit racism sets strict limits on how much social benefit Travellers could gain from formal education. Nevertheless, those who were willing to settle would be rewarded with an elementary education. The Commission stated: 
Arrangements might, however, be made in areas where itinerants settle in houses or approved camping sites to make available to those who wish to acquire it an elementary knowledge of such skills as carpentry, welding, plumbing, elementary repair and servicing of machinery and engines and other similar knowledge which might be of assistance to them in earning a living. (1963: 70)

Travellers were also portrayed as being ignorant in matters of 'health and hygiene' and it was hoped that education and training schemes would amongst other things, promote social decency, cleanliness and order in the publicly visible aspects of family life. At the same time 'tuition in housekeeping, cooking, washing, child hygiene and other domestic knowledge might be made available for the womenfolk...'(1963: 70). It was also noted that:

This lack of education extends beyond the school subjects. They also lack the respect for social conventions, law and order and for the rights of property that are inculcated in the children of the normal family in the settled community by word and example in the home, in the school and in the community generally.... They have little sense of social responsibility ...that the disposition to lack of self-control and the tendency to fight and brawl stems largely from their lack of education and discipline during their formative years. (COI, 1963: 65, 84, 87)

These 'expert' discourses directly intervened in people's perceptions and treatment of Travellers. As Miller and Rose (1992: 177) argue: 'Language is not merely contemplative or justifactory, it is performative'. It is a specific system of thought and of action through which elites seek to give effect to government and was vital in naturalising what were essentially 'political ideas as truth and therefore in bringing people's thoughts and actions in line with political ends' (Prince, 2004: 4). Although knowledge and technologies were being used to control, regulate and 're-mould' Travellers, the official version was that they were working in their interests, 'for their own good'. Irish Travellers needed to be 'rewritten' as people so that they could make a contribution to society.

\section{Economic aspects of the itinerant problem}

If the facts - that is, the behaviour of living human beings - are recalcitrant to such an experiment, the experimenter becomes annoyed and tries to alter the facts to fit the theory, which, in practice, means a kind of vivisection of societies until they become what the theory originally declared that the experiment should have caused them to be. (Isiah Berlin, On Political Judgement cited in Scott, 1998: 347)

This section actually downplayed the significance of its own evidence (see Table 1) and failed to emphasise that a sizeable proportion of Travellers were making a decent living from their nomadic lifestyle and that it was, in fact, the Travellers who were semi-sedentary that were experiencing the greatest level of poverty and deprivation. For example, dealing in scrap and recycling was acknowledged to be widespread:

Almost all itinerants avail of every opportunity that presents itself to obtain scrap or waste material of any description that has a saleable value. Metal of all descriptions, clothes, rags, feathers, horse hair, bottles, jars, and a number of other articles...provide many itinerants with a livelihood of sorts. (COI, 1963: 71-73)

Yet the Commission chose to focus on the dying trade of tinsmithing and used this as justification of the settlement policy in the report. Peddling was not mentioned in the report, 
which, chose instead to include begging as the daily activity of women and children; 'practised almost habitually by every itinerant woman and child' (COI, 1963: 92). The use of the word 'begging' instead of 'peddling' is significant; begging identified Travellers with vagrants and lack of a viable economy. The use of statistics contained in the report was clearly aimed at constituting the Traveller social body rather than merely trying to find out about it.

The Report classified Travellers into four major economic groups: (1) the motor trailer group (horse and other dealers who 'travel extensively'); (2) dealers who travel extensively and whose abode is a horse-drawn caravan; (3) Groups whose travelling is confined to a small area and who have horse drawn caravans; (4) groups whose travelling is confined to a small area and have only tents for shelter. The motor trailer group, dealers and traders, had a good living; 'they are never short of the necessities of life. They are skilled in dealing and trading and well able to provide for themselves and their families' (1963: 80). The second category were dealers in horses and donkeys and scrap 'who travel extensively' were also economically self sufficient although said to be living in 'harsh conditions', 'The families in this group have an income from all sources more than adequate for their needs' (1963: 82). Yet the Commission rather stated: 'Apart from the skills of dealing and begging and as breeders of horses, the only skill which any member of this class possesses is that of tinsmith'.

Up to 460 families were included in these first two groups. The third group, whose travelling was said to be '... confined to a small area' worked as seasonal agricultural workers, dealt in scrap and odd jobs and supplemented their labour with begging (or peddling?). The Commission stated: 'The members of this group have little in the way of skills. They claim to be tinsmiths, sweeps, makers of artificial flowers' (1963: 80). These Travellers, amounting to approximately 350-400 families, were considered to be living just above the poverty line. The last category of Traveller were those who travelled least and had only tents for shelter. Their incomes were estimated to be below subsistence level and were 'largely unemployable' and 'make no contribution to the economic life of the community'.

This lack of context and particularity is not an oversight and according to Scott (1998) it is the necessary first premise of any large-scale planning exercise. Modelling Travellers was an essential aspect of government. Travellers were treated as standardised units because questions posed within strict confines can have definitive, quantitative answers, permitting more precise calculations. The Commission considered '...that a grouping on this basis enables a useful and practical assessment of the overall economic circumstances of the itinerant population to be made' (COI, 1963: 78). What it did was to help create an administrative category of policy analysis out of a vast assortment of divided people (Cruikshank, 1999). The clarity of the Commission's optic was due to its resolute singularity. As with many governmental programmes: 'Its simplifying fiction is that, for any activity or process that comes under its scrutiny, there is only one thing going on' (Scott, 1998: 347). The result was a highly selective social construction of reality. What the policy makers failed to recognise was that at each of these sites or 'groupings' is the intersection of a host of interconnected activities that defy such simple descriptions (Scott, 1998). According to Helleiner (2000: 137) it was their very mobility, their multi-occupationality, and a reliance on unpaid family labour that allowed Travellers to continue to provide competitive goods, services, and labour to the settled community through the economic crisis of the post war period. 
An example of a local level survey of Traveller families carried out by Meath County Council, through its medical officer of Health (1964), showed almost all families were economically self sufficient. It emerged that there were 24 families comprising 145 persons in the county. Of the fifteen families encamped full time, four lived by peddling, another four dealt in scrap metal and the remaining seven were engaged in gainful employment, mainly as farm labourers. The 'tarmac group of families' who were not counted in the survey were said to be ' $\ldots$ in business in an impressive way'. The medical Health Officer, Mr McFadden recommended that a permanent site would not be a good idea as the nature of how they gained their livelihood, through begging and scrap collecting and casual agricultural labourers, meant a permanent site 'would drastically reduce their earning power' (O'Boyles, 1999: 282) (see Table 1).

Adams et al. (1975) refer to an Irish family, the Duffys, who comprised several family groups and whose main occupation was dealing in second hand and antique furniture. These families travelled between Britain and Ireland on a regular basis. According to Adams:

The Duffys have a considerable reputation among English Travellers who envy their collection of modern vehicles festooned with favourite Traveller accessoriesColonel Bogey horns, stereo radio and cassette players, and customized cab fittings. The reputation of the group has passed into the folk-lore of Traveller society, and stories of their fabulous wealth and ability to cover vast distances in short periods are related by many English Travellers. The most surprising thing about the Duffys is their complete absence from the Irish Government's Report. (1975: 179)

The families travelled together in large numbers (as many as thirty at a time) and maintained:

... a wider range of economic status than among the English, several families possessing luxurious trailers towed by lorries with very recent registration plates. At the opposite end of the scale are families with trailers in a very poor condition...(1975: 185)

An acknowledgment that nomadism could be a viable way of life would have challenged a central premise of government policy - i.e., that settlement was the only means through which a higher standard of living could be obtained. 'Official settlement rhetoric thus downplayed both the breadth of Travellers' economic activities and the significance of class disparities within the Travellers population' (Helleiner, 2000: 139).

\section{Settlement strategies}

At the heart of disciplinary and governmental control lies a relation of intimacy between controlling authorities and controlled individuals. Judgement must be seen as credible, or ideally automatic. The individual to be controlled must live their lives in such a way as to be both visible and punishable by authorities. (Hannah, 1992: 240)

Policy makers wanted quick concrete results. Settlement, rehabilitation and assimilation was considered by all political parties, the Catholic Church and charitable organisations to be the most 'humane' way of dealing with Travellers. The rehabilitation policy adopted by the State on the basis of the Commission's recommendations, provided social workers, settlement committees, specialist education facilities, training centres for industrial skills, and halting 
sites as a means to prepare Travellers for assimilation, expanding the apparatus of surveillance and regulation of Travellers' everyday lives. Training centres and social workers would provide supervision and uninterrupted surveillance. Houses and halting sites would provide disciplined spaces and make the official 'gaze' geographically and socially specific.

Whatever its concrete practical differences, disciplinary power involves regulation through visibility and this in turn necessitates spatial fixity. From the 1960s on, the mapping of Traveller's personal mobility became an intrinsic part of Government strategy. The Commission stated that:

All efforts directed at improving the lot of itinerants and at dealing with the problem created by them, and all schemes drawn up for these purposes must always have as their aim the eventual absorption of itinerants into the general community.

This can only be achieved by:

... a policy of inducing them to leave the road to settle down. (COI 1963: 106)

Social welfare programmes were a key technique in the exercise of power and central to government spatial strategies. In order to receive financial assistance Travellers are required to have a fixed address, obliged to provide details of age, accommodation, children, employment status and income. Up until March 1990 every Traveller signing on for welfare assistance had to do so at 11 am on a Thursday, increasing their visibility and accountability. Policy makers ensured that mobility would make it extremely difficult for Travellers to receive welfare payments.

...the procedure which requires unemployment applicants to register at regular intervals is one that is felt that could be used to encourage qualified itinerants to settle in one locality provided, of course, that they were so allowed. The Commission can see no objection in these circumstances to a provision which would require a person of no fixed abode to register at more frequent intervals that the regulation requires for the settled population. (COI, 1963: 76)

The message to Travellers was that 'good behaviour' and the adoption of a sedentary lifestyle would lead to financial assistance. For those reluctant to settle, the Commission recommended a system of rations.

... a substantial amount of the State and local authority assistance including children's allowance given to those itinerants who have not settled down in a fixed abode or who are not regularly spending lengthy periods on approved camping site provided for them...should be paid in voucher form exchangeable for food and clothing so as to overcome abuse by dissipation on intoxicating liquor...those who settle down should, after a probationary period... be paid and treated in every way the same as members of the settled population. (COI, 1963: 76-77)

\section{Settlement committees}

Governmentality by definition involves territory, and can only manifest itself as and through a set of human and material networks (Hannah, 2000). Vital to the human network was the establishment of voluntary bodies known as Itinerant Settlement Committees. These committees were set up within every local authority's jurisdiction in 1969, creating a nationwide settlement movement funded by the State. They can be read as 'a strategy for 
establishing public services and facilities at a sensitive point midway between private initiative and the state' (Donzelot, 1980: 55).

Because within liberal democracies there are typically limits to State power; certain freedoms, rights and activities that are considered outside the legitimate sphere of the State, the Irish government needed to find ways legitimizing the implementation of policies that would infringe on Travellers' autonomy. Also, guaranteeing the long-term moral and social reform of Travellers would demand a subtle and negotiated access to their world. This is where the various Itinerant Settlement Committees were to play a strategic role; they would establish a relation of intimacy between the controlling authorities and the Traveller. Many of their efforts were punitive and coercive but they were put forward as a necessary undertaking in the interests of Travellers and the general population.

The Commission stated:

The main purpose of such committees would be to bridge the gap between the itinerant family and the settled community. It is felt that this can best be done by establishing friendly contact and by regular visitation to obtain their confidence and then to encourage them and their children to learn and adopt the ways of the settled life. (COI, 1963: 107, author's emphasis)

This could best be done by:

...the provision of a variety of services, duties and requirements will be involved, as for instance, arranging ways and means of assisting the education of the children, organising recreations and pastimes, making arrangements for lessons in cookery, housekeeping, hygiene and so on for the adults; helping them to obtain employment and social welfare benefit. (COI, 1963: 107-108)

This form of 'friendly' surveillance is strikingly similar to how Barbara Cruikshank (1999) and Jennifer Robinson (2000) describe the form of management and surveillance involved in the Octavia Hill tradition of housing management. Both address the visual regime of surveillance that enabled the exercise of certain forms of disciplinary power. The friendship model of management developed by the Octavia Hill women brought into view a model of power that stressed friendship, empathy and negotiation (Robinson, 2000: 85). They:

...promoted a system of management based on 'friendship' ... and more or less systematically undertook to visit the poor in their homes to dispense in various proportions, the gospel, Christian charity, domestic training and moral reform. (Robinson, 2000: 69)

In much the same way members of the various Itinerant Settlement Committees had as one of their guiding principles the idea of forming friendships with Travellers and through these friendly interactions they hoped to help settle, rehabilitate and assimilate their subjects. 'The Itinerant Settlement Committees have developed as organisations helping and speaking on behalf of this community' (Sligo Settlement Committee, 1974: 2).

Key words used in settlement policy documents were 'rehousing', 'rehabilitation' and 'resettlement'. Everything distinguishing Travellers from the settled population was seen as a legacy of colonial oppression, backwardness and poverty (Ní Shúinéar, 1997). 
The policy makers believe that the differences in culture have been brought about by poverty and social isolation and that these cultural differences are therefore not worth preserving... This is the premise on which the policy of the Government and Local Authorities has been based. (Sligo Settlement Committee, 1974)

Scientific discourse was mobilised to legitimise claims that Travellers were simply dropouts from Irish society. Crawford's study on 'The Human Biology of the Irish Tinkers' in 1974, claimed that the:

...blood group frequency data and the genetic distances between the Tinkers, sedentary Irish, and Romany Gypsies support... the hypothesis that tinkers are displaced peasants and labourers driven from their lands and occupations by economic upheavals, famine and conflict. (Crawford, 1974: 323)

Although these organisations were set up out of humanitarian concern and many of its members were strongly committed to a more egalitarian society and to meeting the basic needs of Travellers, it is important to recognise the constitutive presence of this discourse whose primary dynamic lay largely external to the disciplinary network, in the end became entwined in disciplinary actions (Herbert, 1996). An examination of the work of these committees helps explain how the Irish State was able to regulate spheres of Traveller society that are not under its direct control. It was through these technologies of government that political rationalities and the settlement programmes that articulate them became capable of deployment. These new modes of social control were sanitized of the apparent influence of 'authority and the state, and were therefore more difficult to oppose and resist' (Fischer, 1998: 188). Members of the settlement committees were drawn into governmental networks through their adoption of common rationalities and forms of calculation. They helped implement the agenda of the state, and were involved in the fabrication of a new moral geography. They employed strategies that entailed education, health, instruction, persuasion, advice, interpretation, and surveillance working largely in conjunction with official bodies in these areas.

It is recommended that the work of such local voluntary committees should be assisted by trained welfare officers whose services would be made available to them by the Minister or the local authority. (COI, 1963: 108)

Members of the committees carried out surveys and laid down detailed regulations for the conduct of Travellers, '...matters of cleanliness, and the elimination of begging, would need constant attention in all cases' (St Jude's Settlement Committee, Navan, 3 January, 1970). They, like all agents of governmentality, 'performed their power via the construction and exertion of knowledge, normalizing discourse (what is acceptable and not acceptable), and an 'inspecting gaze' (Cheong and Miller, 2000: 380). Their ultimate aim was to settle Travellers on sites and in conventional housing, enrol Traveller children in school, 'absorb' and assimilate them into the settled community (Gmelch, 1985: 305). Their more immediate aim was regulate certain factors concerning their 'present modes of living or behaviour which would influence subsequent settlement planning or discussion'. Travellers '...need a good deal of training in some of the essential requirements of settled living; the local Settlement Committee is working on these problems' (St Jude's, 1970: 1).

A reader's letter in The Evening Press (June, 1964) stated:

It is only by settling one family of itinerants in each town or district that they will become industrious, self respecting members of society. The itinerants have no sense of their worth as human beings but it is up to us to treat them as we would have others treat us. 
Settlement Committee members were first and foremost concerned with the moral regulation and reformation of Travellers. Their work was part of the elaboration of technologies of surveillance that sought to create responsible, self-disciplining and selfregulating, citizens (Robinson 2000). It was the internal shift in values and morals (the colonisation of the soul) that was considered crucial by the members of these committees. For example, in 1974, The National Council for Travelling people (this was the new name for the National Itinerant Settlement Committee) recommended that: 'Small families should be encouraged and the teaching of some form of family planning is desirable.' (Fifth Annual Report). For the most part however, it was the external ones like health and hygiene, clean caravans, parenting, discipline, homemaking skills that were the object of the look; the measure of judgement and assessment.

The first step towards ultimate integration of itinerants is the provision by local authorities of serviced camping sites. Such sites provide the necessary springboard for the itinerants.... They give local voluntary groups a working area where they can give the itinerants advice and help them to map out a settled way of life. These sites then act as a bridge between the itinerants and the settled community and help both communities towards mutual understanding. (Irish Times, 15 December 1969)

Through procedures of examination and assessment settlement committee members classified Travellers into indigenous and 'occasionals', those who wished to settle and those who did not, and through practices of improvement into 'deserving' and 'undeserving' Travellers. Those who wished to settle were rewarded with fixed caravans, clothes, financial assistance and skills training. Although for the most part, there was no legally coded stock of punishments, departures from the norm were made punishable through informal punishment, which included shunning, withdrawal of services and assistance. Foucault describes disciplines systematic combination of rewards and punishments as insidious leniencies, unavowable petty cruelties, small acts of cunning' (Foucault, 1979: 308).

The prevailing structures of governmentality are, however, also the consequence of competing, and contradictory forces. In anticipation of settlement programmes and the influx of Travellers to their areas, local authorities immediately set about the task of evicting its nonindigenous Travellers and forcing its indigenous Traveller population into large settlements (often without services) in remote areas and placing boulders and digging ditches on Travellers traditional camping sites (Plate 1). In the Dáil and Local Authority meetings there were increased calls for legislation to restrict movement. Within this environment, Settlement Committee members played out their sympathetic role with constant battles with social services, local authorities, the police and local communities in order to secure accommodation, sites, training and other provisions. This assistance and support guaranteed an ongoing 'friendly' surveillance and a basis for visiting and influencing Travellers - even for those Travellers who were normally hostile or resistant to outside intervention.

Committee members were able to move into spaces previously unobservable, unfettered by any rules, or untouched by formal or legal regulations, as Hopper and Macintosh (1998: 136-137) observed:

One of Foucault's greatest insights is that disciplinary punishment colonised those areas not already ruled by society's judicial system, spaces which were until then the only 'natural' places left for the individual. 
In Foucauldian terms Settlement Committees and halting sites acted as an extra-judicial network of surveillance and discipline handing out their own examinatory justice. It is this totalising imagination of a necessary future that enabled the imposition of such authoritarian and non-liberal forms of rule within a liberal democracy. The proponents of this vision are very much aware however, that what is at stake is not merely administrative convenience but also the transformation of an entire people (Scott, 1998).

\section{Discussion}

The Report of the Commission on Itinerancy marked a shift to a new, more systematic means of governing and controlling Travellers and of extending and consolidating State power. Within the Report and the settlement strategies that followed, the diverse lives and lifestyles of Ireland's nomadic population was homogenised, refashioned and reconstructed through elite discourse and the use statistical inscriptions that permitted their characterisation as a 'group', a 'community' in need of reform.

Paradoxically, however, as technologies and strategies of Government sought to assimilate Travellers and to bring an end to nomadism and its accompanying lifestyle government agents who were supposed to operate and implement the National Settlement Programme exploited for their own ends. Many programmes were hampered by both settled and Traveller resistance; by territorial rivalries between local authorities and by the impossibility of producing the practical conditions that would make the programme work, for example reliable statistics, individual distinguishability, spatial fixity, efficient communications systems, clear lines of command and political will (Miller and Rose, 1990). Mounting frustration and disillusionment with lack of progress in settling, rehabilitating and assimilating Travellers increasingly produced forms of knowledge and a political rationality that viewed Travellers as a group 'without value and beyond improvement' (Dean 1999: 146). Liberal forms of government increasingly slipped from implementing 'well-intended' schemes to improve Travellers condition to ones that overtly confined, contained and coerced, if only by prevention, those who continued to travel.

Meanwhile the social and geographic space within which Travellers traditionally moved continued to be eroded. Most Travellers were now unable to continue with their traditional occupations (for example, scrap collecting) with the result that an overwhelming majority had become dependant on social welfare. This in turn added weight to the Report's statistical representations and appraisal of Traveller lifestyle and increased anti-Traveller feeling amongst the settled community. For example, it was reported in Nusight in November 1969 that:

Since the publication of the Report the instances of victimisation by local residents has doubled. In the Dublin area friction with itinerants has become not only more frequent but more organised. Before the popularity of the cause, prejudice existed but not on a highly conscious level. Then when the Report was issued itinerants became a direct threat to property values. This fear, which the proximity of itinerants brings to the hearts of the middle class, resulted in the highly organised anti-tinker campaign in Stillorgan two years ago and in the bigger Griffith Avenue area this year when all election candidates were pressurised in a disgraceful manner...The Itinerant Settlement Committee found only ignorance six years ago, now they find conscious prejudice...(1969: 35) 


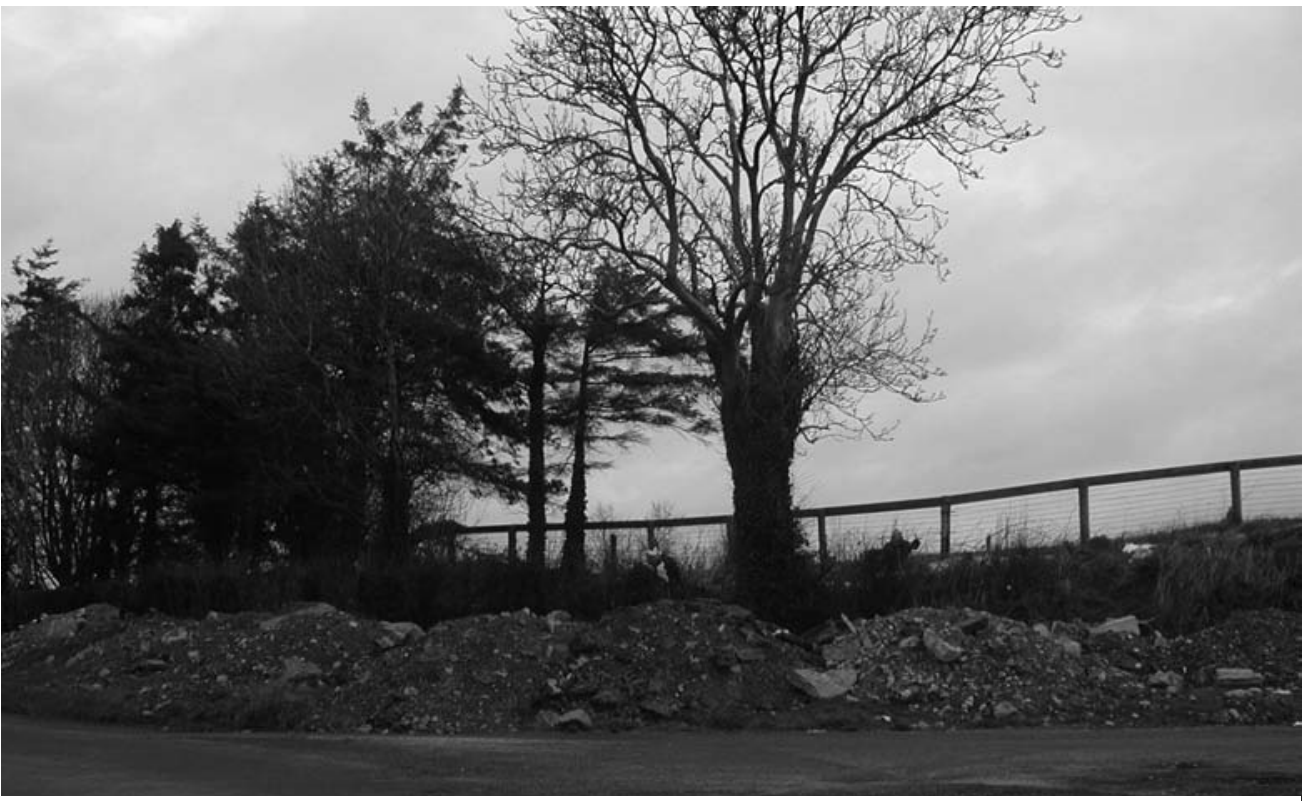

Figure 1: Unofficial boulder policy.

Vigilante attacks became more widespread. According to Gmelch (1977: 36):

In 1968, a member of the Irish Parliament was fined twenty pounds for firing his shotgun at a group of Tinkers camped near his home.

In 1969 Galway was the scene of several vigilante attacks. Instead of castigating the perpetrators the editorial of the Connacht Tribune chose the 'blame the victim' approach and denied there was any racism involved:

This was not the case... of a harmless unoffending people being attacked. The itinerants bring filth wherever they go; they bring fear to many people, and they cause damage to the property of others.... They spread fear, damage and dirt. And yet they deserve a sympathy they did not get in Rahoon. (The Itinerant, 1969: 10, cited in Helleiner 1997: 117)

A letter in the Irish Press declared: 'They should all be sterilised and the kids taken up on the motorway and thrown under the lorries' (22 May 1978). An article in the Irish Times (9 August 1979) Travelling People moved on claimed that it was becoming more common for Travellers to be physically threatened, attacked, and even fired upon with weapons by residents in parts of the country.

The myths, stereotypes and ill-informed assessments contained in the Report quickly congealed to become the 'truth' about Travellers and formed of a stock of knowledge that was and is self-perpetuating and self-reinforcing. This truth had it's own dynamic and started to function (and continues to the present day) as an autonomous producer of other truths and discourses.

\section{Conclusion}

Within the logic of authoritarian governmentality and the rationalities and technologies that emanate from such styles of reasoning, it is of little surprise that a report that gave rise 
to a large archive of paperwork, of correspondence, comparative studies, censuses and statistics, should have been so obstinately silent on the views and experiences of Travellers themselves. Clearly it was a policy and programme not designed for Travellers; it was rather designed for their management, discipline and control. The Commission took complex, traditional types of alliance systems, illegible and traditional social practices such as nomadism, peddling, scrap collecting, horse dealing and created a standard grid. The use of surveys and censuses, served as a technique of decipherment, enabling the chaos of nomadism and Travellers existence to be disentangled. It allowed Travellers to be removed from their individual socio-spatial contexts into a world that could be represented and opened up to political deliberation and intervention and brought inside the policy process. These State simplifications however, were like abridged maps and did not represent the actual activity or lives of Travellers they depicted, nor were they intended to. They represented only the part that was of interest to officials and policy makers (Scott, 1998). The types of information gathered and the way it is and was sorted and accumulated (Latour, 1987) allowed for the creation of a paradoxical fictive space for Travellers. Popular and historical discourse became a resource, which was selectively 'mined'. Travellers 'reality' was now in a form where it could be debated and diagnosed - allowing the 'truth' about Travellers to be told. Travellers were conceptualised as a social and moral problem with certain definable characteristics; they are illiterate, unemployed, pathological and irresponsible.

Such maps of legibility and control, especially when backed by the State do partly succeed in shaping the social environment after their image. The fact that these discourses have not resulted in the end of nomadism and permanent settlement and assimilation of the Travelling Community should not blind readers to the fact that it did, at the very least, damage many of the earlier structures of Travellers' spatial and social traditions. It destroyed many of the skills nomads had on the eve of the National Settlement Programme. And like so many programmes aimed at the settlement of nomadic peoples it also impoverished the ‘...wellsprings of economic, social and cultural expression' (Scott, 1998: 349).

The Report, with its inherent claims to 'truth' and expertise provided the boundaries within which the discursive objects, Travellers, could act and exist. Today, Travellers continue to be governed both through, and by these constructions. The continued failure of the settlement programme has, over the last forty years or so, lead to ever more coercive and punitive measures and attempts to integrate Travellers into wider society '... we do not live in a governed world so much as a world traversed by the 'will to govern', fuelled by the constant registration of 'failure', the discrepancy between ambition and outcome, and the constant injunction to do better next time' (Rose and Miller, 1992: 191).

However, by exposing the false appraisals that 'gave birth to those things that continue to exist and have value for us' (Foucault, 1979: 146) this paper demonstrates that Travellers current status (as one of the most marginalised, disadvantaged and discriminated against groups in Irish society) and the historical processes that gave rise to this situation were discontinuous, divergent and contingent and thus not inevitable.

\section{Acknowledgement}

The author would like to thank Rob Kitchin for his constructive comments on an earlier version of this paper. 


\section{References}

ADAMS, B., OKELY, J., MORGAN, D. and SMITH, D. (eds) (1975) Gypsies and Government Policy in England. London: Heinemann.

BOYLE, D. (1999) A history of Meath County Council: A century of democracy in Meath. Meath County Council.

CHEONG, S. and MILLER, P. (2000) Power and Tourism: A Foucauldian observation, Annals of Tourism Research, 27(2), 371-390.

CHRISTIE, N. (1984) Suitable Enemies. Paper presented at the Howard League $2^{\text {nd }}$ annual Conference on The Individual and the State: The Impact of Criminal Justice. Oxford.

CRAWFORD, M.H., and GMELCH, G. (1974) The Human Biology of Irish Tinkers: Demography, Ethnohistory, and Genetics, Social Biology, 21, 321- 331.

CRESSWELL, T. (2001) The Tramp in America. London: Reaktion Books.

CRUINKSHANK, B. (1999) The Will to Empower: democratic citizens and other subjects. London: Cornell University Press.

DANAGHER, G. (2000) Understanding Foucault. London: Sage Publications.

DEAN, M. (1999) Governmentality: Power and Rule in Modern Society. London: Sage.

De CERTEAU, M. (1984) The Practice of Everyday Life. Berkeley: University of California Press.

DONZELOT, J. (1980) The Policing of Families. London: Routledge.

ENNIS, M. (1984) The Victims. Dublin: The Committee for the Rights of Travellers.

FISCHER, B. and POLAND, B. (1998) Exclusion, 'Risk' and Social Control - Reflections on Community Policing and Public Health, Geoforum, 29(2), 187-197.

FOUCAULT, M. (1980) The History of Sexuality: An Introduction. Hardmonstown: Penguin.

FOUCAULT, M. (1982) Afterword: The subject and Power, In: Dreyfus, H. and Rainbow, P. (eds) Beyond Structuralism and Hermeneutics. Chicago: Chicago University Press, 208-226.

GMELCH, G. (1977) Settling the Irish Tinkers, Ekistics, April (257), 231-239.

GMELCH, G. (1985) The Irish Tinkers: the urbanisation of an itinerant people (2nd edition). Wavelength Press: Prospect Heights.

GUTTING, G. (1994) The Cambridge Companion to Foucault. Cambridge: Cambridge University Press.

HALL, S. (1997) The Spectacle of the 'other', In: Hall, S. (ed.) Representation: Cultural Representations and Signifying Practices. London: Sage Open University.

HANNAH, M. (1992) Foucault deinstitutionalised: Spatial pre-requisites for modern social control. Unpublished Ph.D thesis, Pennsylvania State University.

HANNAH, M. (2000) Governmentality and the Mastery of Territory in nineteenth-century America. Cambridge: Cambridge University Press.

HELLEINER, J. (1995) Gypsies, Celts and Tinkers: Colonial Antecedents of Anti-Traveller Racism, Ethnic and Racial Studies, 18(3), 532-54.

HELLEINER, J. and SZUCHEWYCZ, B. (1997) Discourses of exclusion: The Irish Press and the Travelling People, In: Riggins, S. (ed.) The language and Politics of Exclusion: Others in Discourse. London: Sage, 109-130.

HELLEINER, J. (2000) Irish Travellers: Racism and the Politics of Culture. London: University of Toronto Press.

HERBERT, S. (1996) The geopolitics of the police: Foucault, Disciplinary power and the tactics of the Los Angelus Police Department, Political Geography, 15(1), 47-57.

HOPPER, T. and MACINTOSH, N. (1998) Management Accounting Numbers: Freedom or Prison Geneen versus Foucault, In: McKinlay, A. and Starkey, S. (eds.) Foucault, Management and Organization Theory. Sage: London, 126-150.

HUNT, A. (1994) Foucault and the Law: Towards a Sociology of Law and Governance. London: Pluto Press.

KEARNS, K. (1978) Population Shift and Settlement Patterns of Irish Travellers, Irish Geography, 11, 23-33.

LATOUR, B. (1987) Science in Action. Cambridge: Harvard University Press. 
LEE, J.J. (1979) Ireland 1945-70: continuity and change in Ireland, In: Lee, J.J (ed.) Ireland: 19451970. Dublin: Gill and MacMillan, 166-178.

Ní SHÚINÉAR, S. (1997) Why to Gaujos hate Gypsies so much anyway? In: Acton, T. (ed.) Gypsy Politics and Traveller Identity. Hertfordshire: University of Hertfordshire Press, 26-53.

Ní SHÚINÉAR, S. (2002) Othering the Irish (Travellers), In: Lentin, R. and McVeigh, R. (eds) Racism and Anti-Racism in Ireland. Belfast: Beyond the Pale Publications.

MacLAUGHLIN, J. (1995) Travellers and Ireland: whose country, whose history? Cork: Mercier Press.

MILLER, P. and ROSE, N. (1990) Governing economic life, Economy and Society, 19(1), 1-31.

MURDOCH, J. and WARD, N. (1997a) Governmentality and territoriality; the statistical manufacture of Britain's "national farm", Political Geography, 16(4), 307-324.

PILE, S. (1995) Mapping the subject, Mapping the Subject: Geographies of Cultural Transformation. London: Routledge.

PRINCE, R., KEARNS, R. and CRAIG, D. (2004) Governmentality, discourse and space in the New Zealand health care system, 1991-2003, Health and Place. (in press).

PROCACCI, G. (1991) Social Economy and the Government of Poverty, In: Burchell, G., Gordon, C. and Miller, P. (eds) The Foucault Effect: Studies in Governmentality. Chicago: University of Chicago Press, 151-168.

ROBINSON, J. (2000) Power as Friendship: Spatiality, femininity and 'noisy' surveillance, In: Sharp, J., Routledge, P., Philo, C. and Paddinson, R. (eds) Entanglements of Power: Geographies of Domination and Resistance. London: Routledge, 67-92.

ROSE, N. and MILLER, P. (1992) Political power beyond the state: problematics of government, British Journal of Sociology, 43(2), 172-205.

ROSE, N. (1996) Inventing our selves: psychology, power and personhood. Cambridge: Cambridge University Press.

SLIGO COMMITTEE FOR TRAVELLING PEOPLE, (1974) Social Contract. Sligo: Private.

St JUDE'S SETTLEMENT COMMITTEE, Newsletter, Navan, 3 January 1970.

SAID, E. (1978) Orientalism. New York: Random House.

TOWNLEY, B. (1998) Beyond Good and Evil: Depth and Division in the Management of Human Resources, In: Starkey, A. and McKinlay, K. (eds) Foucault, Management and Organization Theory. London: Sage Publications, 191-210.

Van DIJK, T. (1997) Political discourse and racism: Describing others in Western Parliaments, In: Riggins, S. (ed.) The Language and Politics of Exclusion: Others in discourse. California: Sage, 31-64.

ROSE, N. (1996) The death of the social? Re-figuring the territory of government, Economy and Society, 25(3), 327-356.

SIMONS, J. (1995) Foucault and the Political. London: Routledge.

STROLER, A.L. (1995) Race and the Education of Desire. Durham, NC: Duke University Press. 


\begin{tabular}{|c|c|c|c|c|c|}
\hline 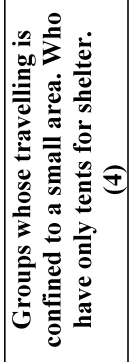 & 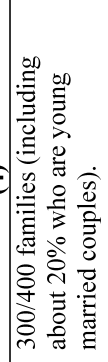 & 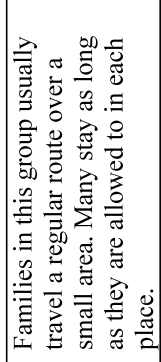 & 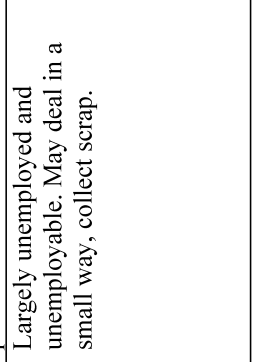 & 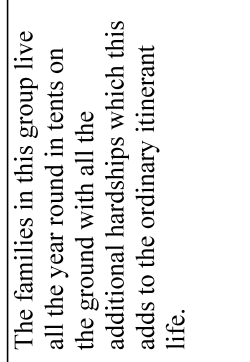 & 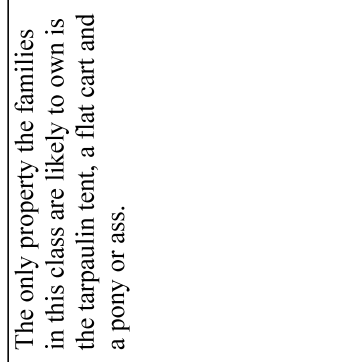 \\
\hline 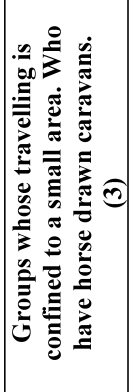 & 象 & 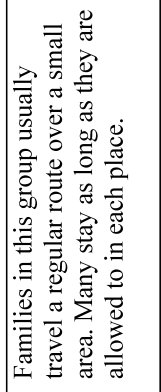 & 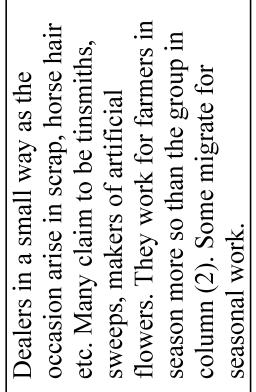 & 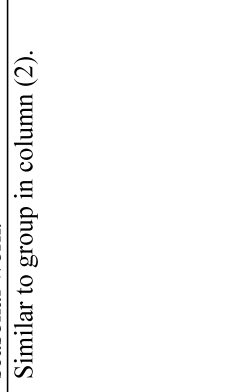 & 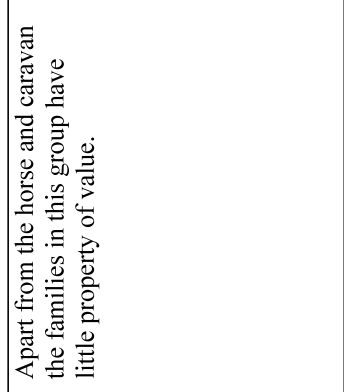 \\
\hline 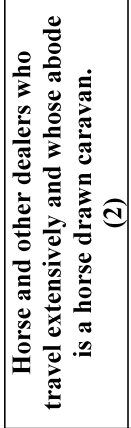 & 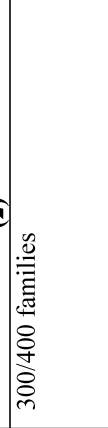 & 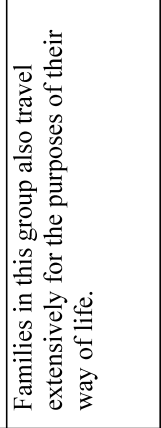 & 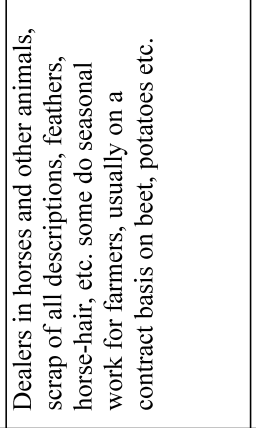 & 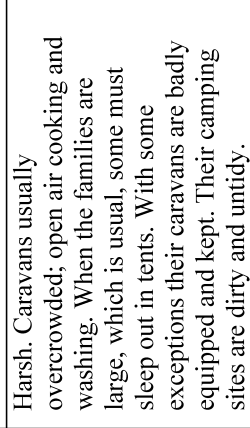 & 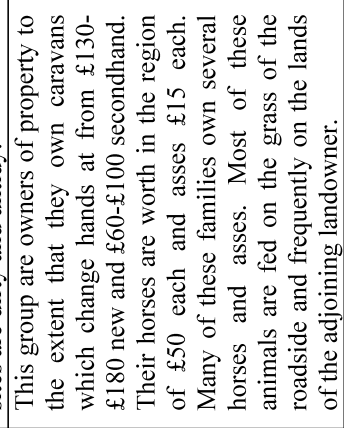 \\
\hline 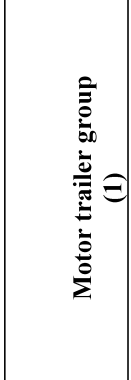 & 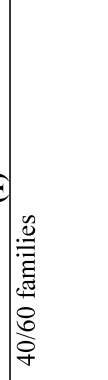 & 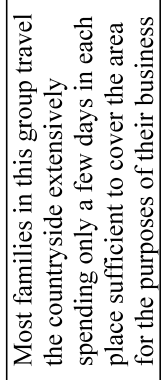 & 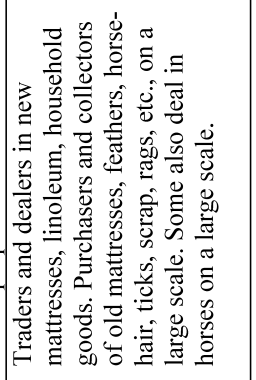 & 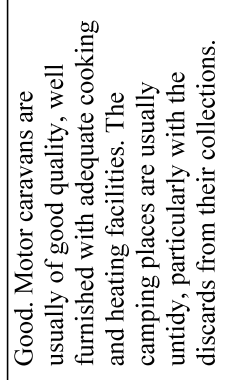 & 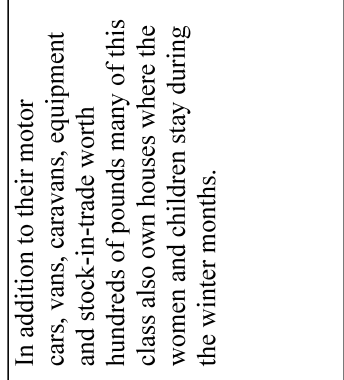 \\
\hline 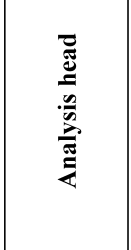 & 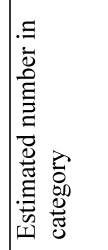 & 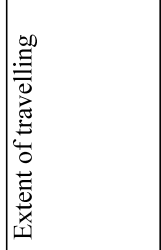 & 0 & 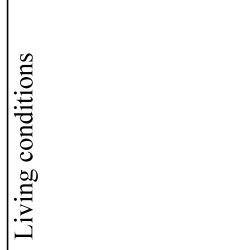 & 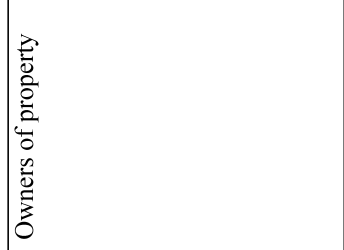 \\
\hline
\end{tabular}

Table 1: Economic classification of Itinerant families. Source: COI (1963: 79: 82). 


\begin{tabular}{|c|c|c|c|c|}
\hline 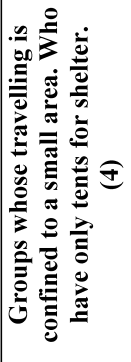 & 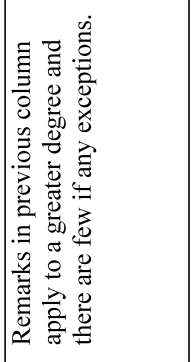 & 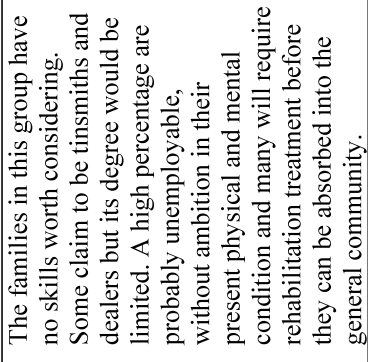 & 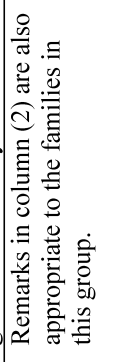 & 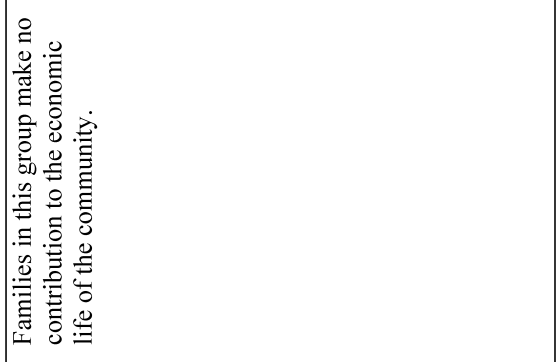 \\
\hline 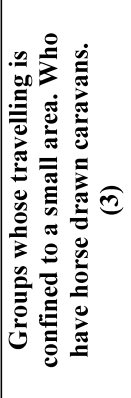 & 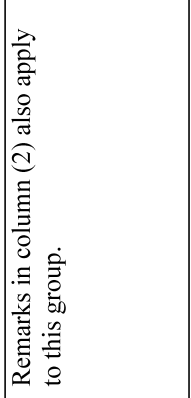 & 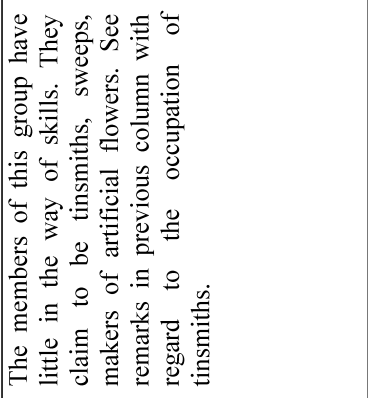 & 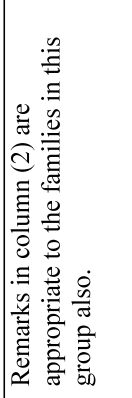 & 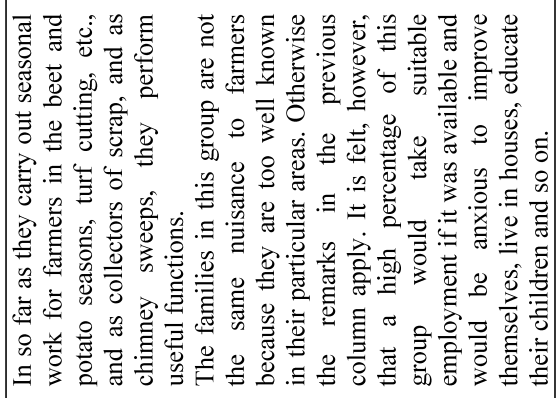 \\
\hline 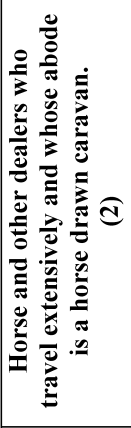 & 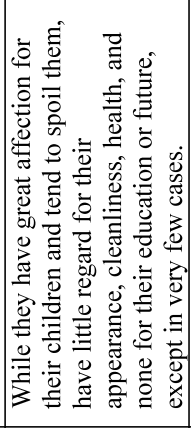 & 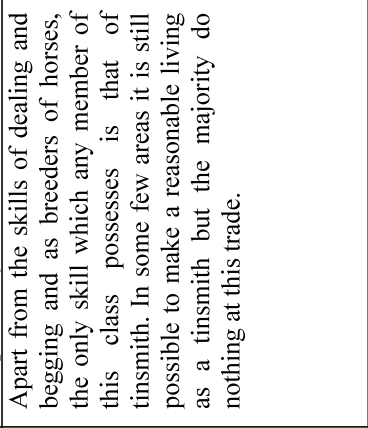 & 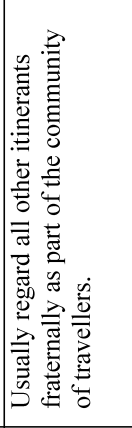 & 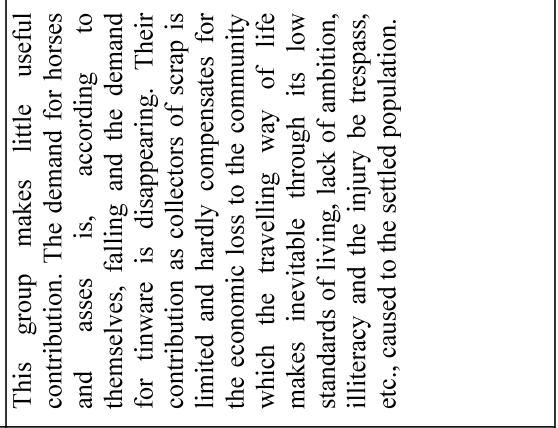 \\
\hline 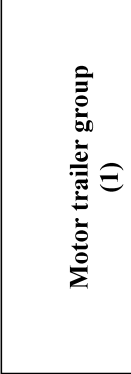 & 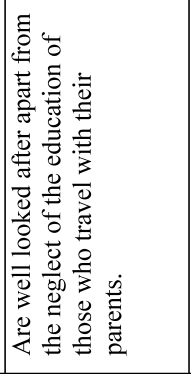 & 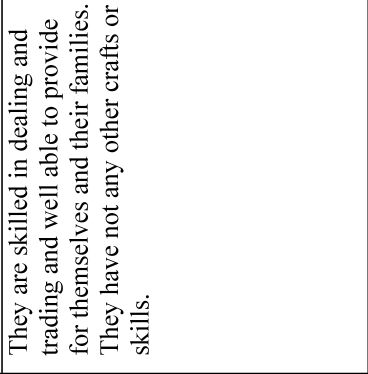 & 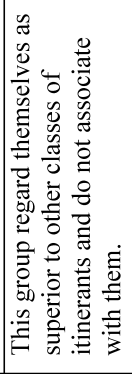 & 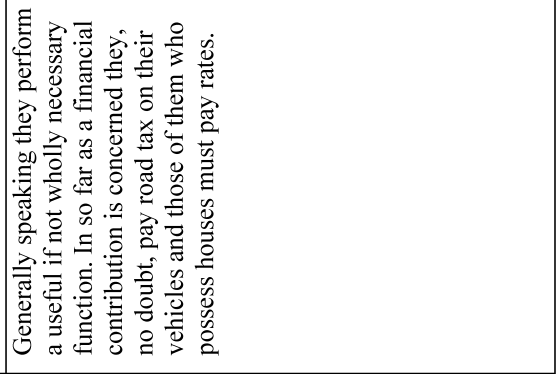 \\
\hline 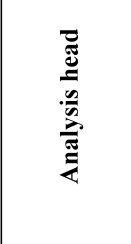 & 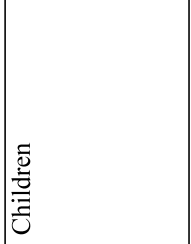 & $\frac{\pi}{\infty}$ & 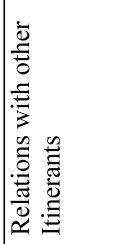 & 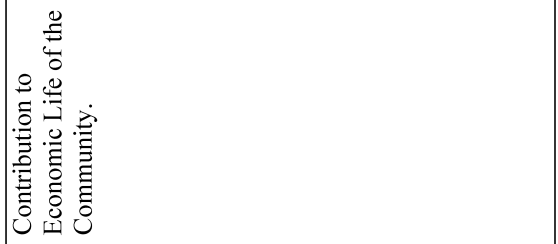 \\
\hline
\end{tabular}

Table 1: Economic classification of Itinerant families. Source: COI (1963: 79: 82). 


\begin{tabular}{|c|c|c|}
\hline 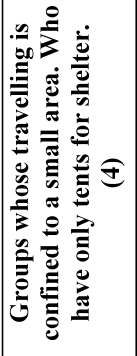 & 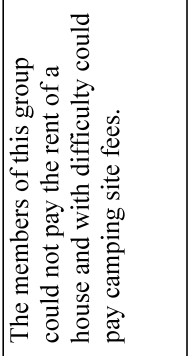 & 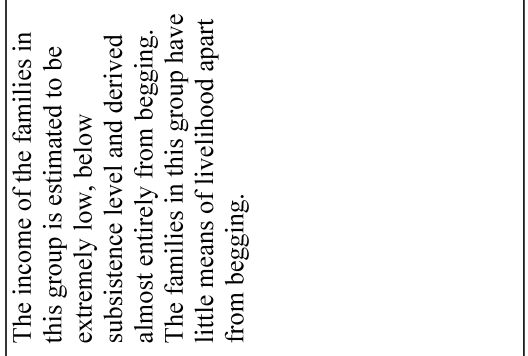 \\
\hline 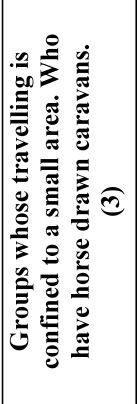 & 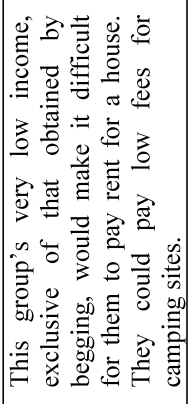 & 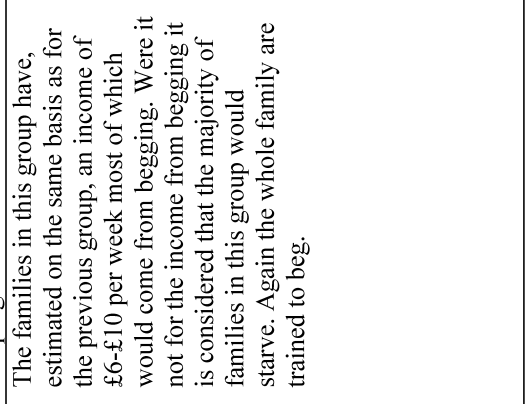 \\
\hline 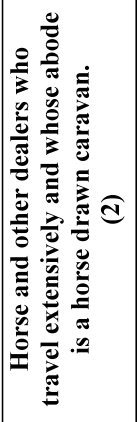 & 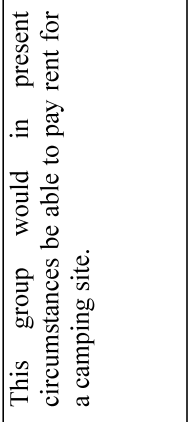 & 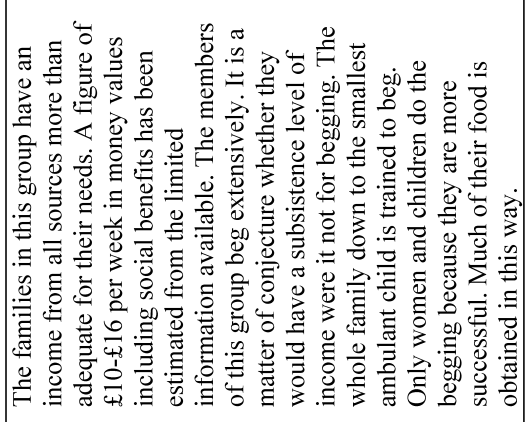 \\
\hline 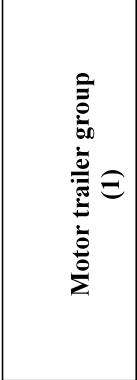 & 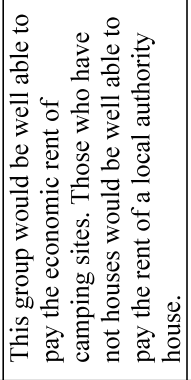 & 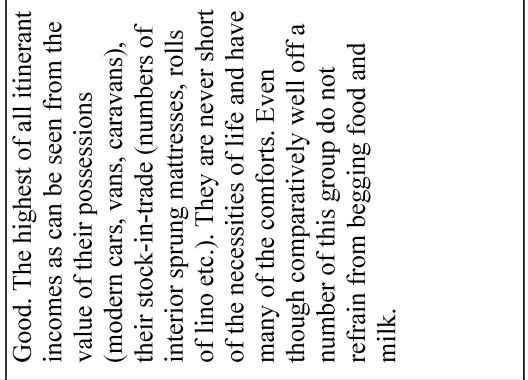 \\
\hline 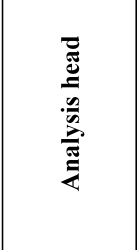 & 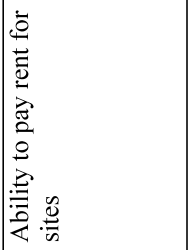 & 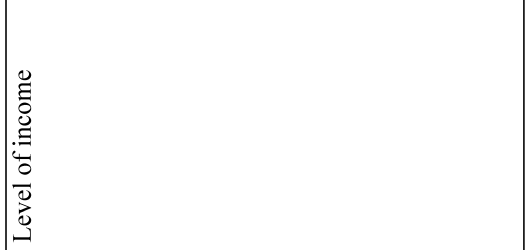 \\
\hline
\end{tabular}

Table 1: Economic classification of Itinerant families. Source: COI (1963: 79: 82). 